\section{MARJÁN Attila}

\section{VÁLLALATIRÁNYÍTÁSI SZABÁLYOZÁS, MENEDZSMENTKULTÚRA ÉS EURÓPAI VERSENYKÉPESSÉG}

Az alábbi cikk azt kívánja megvizsgálni, hogy a vállalatirányítási szabályok mennyiben képesek befolyásolni az európai versenyképességet, másrészt azt, hogy az Európában elterjedt vállalatirányítási gyakorlat, illetve vezetối mentalitás hogyan hat a versenyképességre. A cikk röviden számba veszi a vállalatirányítási és finanszírozási rendszerekre vonatkozó elméleti eredményeket, emellett összehasonlítja az európai és az amerikai gyakorlatot, és részletesen foglalkozik az EU vállalatirányítási reformjainak közelmúltbeli hullámaival és a tagállamok modernizációs erófeszítéseivel.

Kulcsszavak: vállalatirányítás, menedzsmentkultúra, versenyképesség

Az Európai Unió, illetve az EU-tagállamok versenyké- - szemszögéból is. Az USA-nak a 90-es évek eleje óta pessége sok tényezó együttes hatásától függ. Ilyen fon- meglévố gazdasági erőfölényét sokan éppen pénzügyi

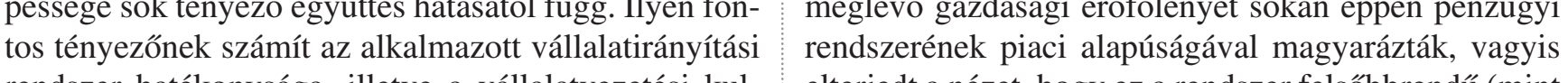
rendszer hatk túra, a nésén késóbb látjuk, amikor a másik modell országai növeszámtalan aspektusa van, ebben a cikkben szelektíven kedtek jobban, azok modellje lett felsóbbrendúnek fogjuk megközelíteni a kérdést.

Európa sok tekintetben az Egyesült Államokhoz méri magát, az USA hol mintaként, hol (és ez a ritkább, de a válság óta azért egyre gyakoribb jelenség) elrettentő példaként szolgál Európa számára. A 2008-tó felerôsödő pénzügyi-gazdasági válságért gyakorta az amerikai pénzügyi szektor múködését és annak szabàlyozatlanságát teszik felelőssé, amiben sok igazság van. Mint ahogy abban is, hogy a két kontinens vállalatfi-

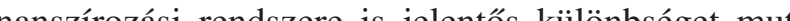
Kezdjük először ennek gyors megvizsgálásával, met Kezcjuk lószor enek gyos megvizsgálásával, mert ez segíthet a ket kontinensen bevett vallalatirányítás gyakorlatban való eltések jobb negértéseben is! Az európai kontinentális pénzügyi rendszerek jellemzően bankok âtal közvettett forrásokon alapulnak. Az amerikai (és a brit) pénzügyi rendszerekben az értékpap rosodás sokkal nagyobb mértékú. Az euróövezetben vállalati kötvénypiacok és a részvénypiaci kapitalizáció is sokkal alacsonyabb, mint az Egyesült Allamokban.

A fenti elvi piaci-mechanizmusbeli különbség az európai-kontinentális és az amerikai pénzügyi rendszer között vizsgálat tárgya lehet a gazdasági fejlődés eltéró pénzügyi rendszerek növekedésre való hatását elemezték, nem bizonyultak egyértelmúnek, sốt a válság során kiderült ennek a rendszernek a kellő szabályozás hiján való sérulékenysége. Igaz, hogy a válság pillanatok alatt átterjedt a bankszektorra is, ami jól szemlélteti a pénzügyi rendszer különböző részeinek rendkívül erôs összefonódottságát.

\section{Piaci vagy banki alapú}

A mikroökonómia szintjén a pénzügyi struktúrákban lévő különbségek jelentôséggel bírnak a befektetési projektek felmérése és kiválasztása során, illetve a vállalati kontroll kialakítása szempontjából is. A piaci alapú vagy a banki alapú pénzügyi rendszer felsóbbrendúsége az adott befektetési projekt sajátosságaitól függ, mint például szükséges-e a tulajdonosokra vonatkozó információ nyilvánosságra hozása, vagy szükség van-e a tốkekölcsönző részéról a hosszú távú elkötelezettségre.

A piaci alapú rendszer általában hatékonyabb a gazdasági bizonytalanságok kezelésében. Minél nagyobb a jövố eseményeire vonatkozó saját, független vélemény nyel rendelkezô résztvevốk száma, annál valószínúbb, hogy az aggregát nézet a helyes valószínúségi eloszlás fogja tükrözni. Például egy piaci alapú rendszer jobba képes összesíteni a vélekedéseket az új technológiákra vonatkozóan. Az ebben való bizalom a gyakorlatban az elmúlt években megdólni látszott, az internetbuborék, illetve a jelzálogbuborék kipukkanása során. Ezzel kapcsolatban megjegyezzük, hogy a világgazdaságban elképesztô méretú dezinformációs tevékenység zajlott le az auditorok, hitelminósítók és elsósorban a befektetési tańcsodók részérốl. Ennek a jelenségnek egyes helyeken a piaci modell fejlódésének megtorpanása lett a következménye.

A banki alapú finanszírozás alapvetóen a hosszabb távú projektek esetében hatékonyabb. Egy bank kifejezett elkötelezettsége egy beruházási projekt melett más, kisebb befektetóket is a projekthez vonzh nagymértékben csökkentve a projekt felméréséhez és monitoringjához kapcsolódó költségeiket. Továbbá cégek gyakorta vonakodnak belső, bizalmas üzleti információkat nyilvánosságra hozni, ezért preferálják ezt a megoldást.

Ahogy a vállalati finanszírozási szükségletek változnak az adott cég életciklusának előrehaladásáva a pénzügyi rendszerek hatékonysága a cégek számáa pénzugyi rób oly tényezókön múlik, mzamá

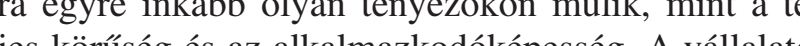
jes kốrúgég és az alka számára múkôdésth kezdeti szakaszában valószinúleg a banki finanszíozás a kedvezôbb, mig az érettebb és nagyobb cégek számára kedvezôbb megoldás lehet direkt tôkepiaci megjelenés, fôleg nagyszabású átalak tási vagy felvásárlási, fúziós akciók végrehajtásához.

A pénzügyi rendszerek különböző́sége alapvetóe a tradicionális vállalatirányítási és finanszírozási megoldások különbözőségéból ered. A vállalatirányítás és a piacok likviditásának problémája az utóbbi évekbe sokat kutatott témává vált. Nincs egyetértés a szakértốk között abban, hogy mi a legjobb intézményi megoldśs a hatékony vállalatirányítás biztosítására. A fejlett via hatékony vállalatirányíás bizlositásara. A rejlett vilténón elterố megoldások alak lyen gyökereznek a társadalom sajâtosságaiban, ezét nehezen váloztathatok meg. Megváloztatásuk sok más területen idézhet eló problémákat, alkalmazkodás kényszereket. A kérdés tehát igen bonyolult, és éppen ezért van nehéz helyzetben az Európai Unió is, amikor bármiféle harmonizációt kíván véghezvinni ezen területen. A gyakorlatban egy nemzetállami társasági jogrendet alapvetően befolyásoló közösségi irányel elfogadása akár évtizedeket is igénybe vehet. Az EU ban ennek megfelelóen nincs is olyan irányelv, amely az irányítás problémáját átfogóan szabályozná. Ám számos, a társasági jog területére, illetve a tókepiacokra és penzügyi szolgáltatásokra vonatkozó EU-irányelv jelentốs mértékben befolyásolja a vállalatirányítás múödését, lehető́ségeit.

\section{Belsố és külsố irányítási rendszerek}

Ténykérdés, hogy a finanszírozási döntések nem tisztán a pénzügyi logika vagy a vezetói önérdek alapján szïletnek Számos szabályozási, történelmi, kulturális és egyéb tényez" befolyásolja azokt. Alapvetôen belsô es kulsô ín bét enszírozási státus

A külsó rendszerekben rendszerint egyszintú a vezetés, amelyben helyet kapnak a tényleges vezetéssel megbízott menedzsment tagjai és a részvényesek érdekeit képviselô nem menedzsment tagok. Rendszerint kisrészvényesek sokasága a tulajdonos. E tulajdonosok nem szakmai, hanem tipikus pénzügyi vagy portfólióbefektetók, akik nem tudják és nem is akarják gyenge teljesítmény esetén a vállalatot átszervezni. Elégedetlenség esetén inkább eladják a részvényeiket, ami az árfolyam eséséhez és ellenséges - azaz a menedzsment akaratával ellentétes - vállabtfelvásárláshoz vezethet. Ez a rester Eź féct félyok igénel a papín kerá bályokat igennyel a papírok kereskedésére, és ez likvid rêszvénypiacok mellett múköödóképes. A tôzsdei értékelés lesz a vezetốk javadalmazásának alapja, amivel a részvényesek és a vezetés érdekei közötti konfliktust csökkenthetik. Külső rendszerú országok hagyományosan az USA és az Egyesült Királyság.

A belsó rendszerek fóként az egyéb kontinentális európai és japán vállalatokra jellemzók. Ebben a vezetés feletti ellenôrzést valamely erôs, domináns, belsố érdekeltségú partner végzi, miközben egyéb csoportok is hatást gyakorolnak a vezetésre. Ez utóbbiak a formákaválík a bankok es egýb penzlgyi befektónigyi befektetôk, helyíkozosségek, a kormany és az ügyfelek (vevók és eladok). Az ertékpapírpiacok gyakran nem játszanak fontos szerepet sem az ellenơrzésben, sem a vállalatfinanszirozásban. A vezetéssel szemben elvárás nemcsak a részvényárfolyam emelése - gyakran nincs megfelelố likviditású piac, nincsenek szigorú kereskedési, vállalatvételi szabályok, az árfolyam-átalakulás információtartalma alacsony, vagy az érdekeltek egyszerúen alárendelt kérdésként kezelik -, hanem a különbözó érdekek közötti egyensúly, a konszenzus megtalálása. 
Gyakori a koncentrált részvénytulajdonlás és birtoklás vagy a koncentrált hitelezés, a vállalatok közötti részvény-kereszttulajdonlás. Az ellenséges tőzsdei vállalatfelvásárlások ebben a rendszerben szinte teljese ismeretlenek. A tagállamok között húzódó fenti vállalatirányítási szakadék volt a fó oka annak is, hogy a vállalatátvételról szóló irányelvtervezetet hosszú-hosszú ideig lehetetlen volt elfogadni.

A vállalatirányítási rendszerek összehasonlító elemzésének egyik ösztönzője a nyolcvanas években a globális verseny során az amerikai és a brit cégek versenyképességének csökkenése, a német és japán cégek gyors növekedése volt. Azt feltételezték, hogy az eltérô eredmények mögött részben a finanszírozás eltérô mintái játszanak szerepet. Ezek pedig az irányítási rendszerek különbözőségén alapulnak.

A belső rendszerekben a hiteleszközök esetében a bankhitel a tipikus forrás. Ez lehetôvé teszi a fốkép családi, egyéni tulajdonosoknak, hogy a tulajdonjogukat megőrizzék. Igaz ez a német kisvállalkozásokra is, amelyek nem szívesen mondanak le a kizárólagos beleszólásukról. A német bankok sajátos szerepet játszanak azzal, hogy miközben bankhitellel finanszírozzák a vállalatokat, a hosszú távú forrásokat ehhez saját kötvényeik kibocsátásával szerzik. A hiteleszközök tipikusan koncentrált tulajdonban vannak, és piacuk illikvid. Szabályozási és adórendelkezések is gátolhatják a piaci vállalati hiteleszközök kibocsátását és forgalmát. A rövid és az éven túli vállalati hiteleszközök kibocsátását és forgalmát diszpreferálták Németországban kibocsátás engedélyezési eljárásai, illetve az átruházá adóterhei.

Ez a mentalitás a részvényeket nem finanszírozás eszköznek és nem is pénzügyi befektetésnek tekinti, hanem a tulajdonlás eszközének. Azokat nem a rôvid tává árfolyamnyereség érdekében, hanem a vállalat irán hosszú távú elkötelezettség miatt tartják. A részvényes maga vagy megbízottja útján rendszerint aktívan él a jogaival. Nincs nagy, likvid, másodlagos részvénypiac, nem jelentốs finanszírozási forrás az elsődleges kibocsátás, a részvények tulajdonlása koncentrált, a részoe-

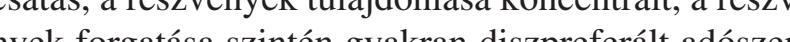
nyek forg

A belső rendszerek finanszírozási szerkezete tehá egyértelmúen nem kedvez a likvid értékpiacok kial kulásának. A piacoknak nincs ellenőrző funkciójuk vezetés, vagy tágabban a vállalat teljesítménye felett. A koncentrációval a finanszírozó kockáztatja az elégtelen diverzifikációkból adódó veszélyek bekövetkeztét. A tókeáramlás intézményeken, nem pedig személytelen piacokon valósul meg. A tóke visszaforgatása mellet erős érdekeltség mutatkozik, még akkor is, ha pénzügyi szempontból egy más területen hatékonyabb felhasznásra volna lehetőség.

Az utóbbi idóben Európában is megfigyelhetô egy jelentôs elmozdulás a piaci modell felé. Az eurózóna részvénypiacának jelentősége idővel nőtt. Amíg 1990től 1995-ig a piac kapitalizációjának és a GDP-nek az aránya $25 \%$ körül volt, ami így messze alatta maradt Japán és az USA értékének, a részvénypiac átfogó növekedése az euró zónában oda vezetett, hogy az arány 2000 végére több mint $90 \%$-ra nőtt. Tehát az eurózóna piacának kapitalizációja a GDP-hez viszonyítva nagyobb, mint Já́f́ (68\%). Ugyanakor nemzetközgyobb, ossźn Cának nagyobb mérete.

Osszegzésül elmondható, hogy kétévtizeddel ezelôtt az európai vállalatok zöme bankhitelekre támaszkodott, és mindössze 20 százaléka finanszírozta növekedését a tókepiacokról, és bár mára ez az arány már 60 százalékra nőtt, még mindig számottevően elmarad a csaknem 90 százalékos amerikai értéktól. A konvergencia jelei azonban látszanak, mert - jóllehet - a részvények itt sohasem számítottak olyan mindennapos „háztartási cikknek", mint az USA-ban, Németországban ma már több mint 6 millióan részvénytulajdonosok, NagyBritanniában pedig minden harmadik felnőttnek van részvényan pedig mínen hafmadík felnôttnek van európ europar piaz in Én katarozó szebefortési sán befektetési szabályai hagyományosan jóval engedékenyebbek. Ezen a téren viszont a válság miatt minden bizonnyal jelentós valttozás várható a hedge fundok (fedezeti alapok) szabályainak erôteljes megszigorításával párhuzamosan.

\section{A vállalatirányítási szabályozás}

Nézzük meg röviden, hogy az EU milyen reformokat hajtott, illetve hajt végre a vállalatirányítási szabályozás területén! A befektetói bizalom, a befektetések védelme, a pénzügyi és vállalati visszaélések visszaszorít́s modern, a vátoź́ gazdári kömnezethez igazod tárś jogi es valla kérón társasági jogi es vallalatianyitási szabályozási környezetet feltéclez. Mindez természetesen nemzetközi szinten, a tagállami szabályozásbeli különbségek csökkentesével, kiegyenlitesével zajlik, hiszen ezek a feltételek határon átnyúló jelleggel kell, hogy teljesüljenek. A vállalatirányításra vonatkozó szabályozás sikerének záloga a rugalmasság biztosítása, az önszabályozó törekvések elósegítése és az önszabályozás kereteinek biztosítása. Ezen a területen EU-szinten nem a kötelezó erejú jogforrásoké, hanem a kellő mozgásteret és vá- lasztási lehetốséget biztosító ajánlásoké, iránymutatásoké a fốszerep, de bizonyos alapkérdésekben kötelezô EU-normák is kívánatosak

Az Európai Bizottság a vállalatirányítási szabályok területén tehát alapvetően nem törekszik teljes harmonizációra. A kitúzött célok elérését az alapvetố elvek és szabályok meghatározása mentén látja megvalósíthatónak, annak hangsúlyozásával, hogy az elvek kijelölése és közös elfogadása nyomán a társaságokra nehezedó morális és piaci nyomás egyaránt kiegészítheti, illetve pótolhatja a kötelezô EU-szintú rendelkezéseket. ve pótolhatja a kotelezó EU-szintú rendelkezéseket. E gondolatmenet nyomán került sor az ajánlás, mi közösségi jogforrás alkalmazására a vállalatirányít si szabályozási rendszerben', abban bízva, hogy az ajánlásokban foglaltak hamarabb érvényesülnek, mi a meglehetósen hosszadalmas eljárást igénylő uniós irányelvi vagy rendeleti szabályok. Érdemes kitérni továbbá a ,betartani vagy megmagyarázni” elv (vagy a
„tartsd be, vagy ha nem tartod be, magyarázd el, hogy miért nem" elv) alkalmazására, amely elterjedt a vállalatirányítás szabályozási területén. Ennek keretében a társaságokat felkérik, hogy hozzák nyilvánosságra, betartják-e a vállalatirányítási kódexet, illetve magyarázzák meg az attól való bármiféle lényeges eltéréseket. Ez a megközelítés lehetővé teszi a társaságok számára, hogy megmutassák az ágazat- és vállalatspecifikus követelményeket, a piac számára pedig azt, hogy értékelje a megadott magyarázatokat és indoklásokat.

A reformtörekvések és a szabályozás iránti igény felerốsödésének hátterében a vállalati visszaélések botránysorozataként elhíresült ügyek állnak, amelyek közül Európa számára a Parmalathoz kötődố visszaélések voltak a leginkább megrázóak.

\section{A Parmalat-botrány}

A cég torékeny pénzügyi helyzetére 2003 végén derült fény, amikor nyilvánosságra került, hogy a kilencvenes évek közepétól 2001-ig a Parmalat éves rúgott. Mindeközben a társasági eredmények pozitív számokat mutattak, folytatódott az eurókötvények kibocsátása a tényleges pénzügyi helyzetre tekintet nélkül. A vállalat nettó adóssága ekkor már 14,3 milliár euróra volt becsülhetố. Az élelmiszer-ipari konszern, amely Olaszország hetedik legnagyobb vállalkozás és amely harminc országban 36 ezer embert foglalkoztat, közel egy évtizeden keresztül tévesztette me befektetóiit. Az európai Enronként emlegetett pénzügyi visszaélések nyomán szemléletváltozást és szabályozási környezetnek az átláthatóság szolgálat ba állítását szorgalmazta a befektetői piac.
A vállalati botránysorozat és az általános bizalmi válság kapcsán az Európai Bizottság az alábbi öt fontos tanulságot vonta le. Az elsó́, hogy újra szükség van arra, hogy a befektetók elhiggyék a vállalati számokat. Ehhez az auditszakmának és az auditelveknek meg kell újulniuk. Másodsorban a menedzsment ösztönzési rendszere a biztonságos üzleti múködést kell, hogy szolgálja. Nem lehet kizárólag a részvényárfolyam emelkedésétôl függoővé tenni a díjazást, és ezáltal etikátlan és a realitásoktól elszakadó vezetési gyakorlatra ösztönözni a menedzsmentet. Harmadrészt a cégeknek fel kell ismerniük, hogy befektetók védelme nekik is jó! Fel kell isme nilk, hogy az elsó és legfontik is jo. Fel kell ismenilk, hogy az elsó es legfontosabb felôs. A ne gyedik ele az, hogy a befektetôknek filiö. A negyedik elen az, hogy a befektoknek, s külonôsen a nagy intézményi befektetóknek aktívabban részt kell venniluk a cégek eletében. Nekik ott kell lenniük a közgyúléseken, és meg kell követelniük az alapos és tényszerú tájékoztatást. Az ötödik és legfontosabb tanulság azonban az, hogy az etikát nem szabad a pénzszerzés mögé sorolni. Egy olyan gazdasági rendszer, amelynek legfontosabb szereplói az etikai alapokat figyelmen kívül hagyják, kudarcra van ítélve.

\section{Az intézkedéscsomag}

A fenti tanulságok gyakorlatba ültetésére az Európa Unió egy hételemú intézkedéscsomagot ${ }^{2}$ indított útjára, amelyek közül itt részletesebben a vállalatirányítási eformmal foglalkozunk.

A reformok elókészítése érdekében egy magas szintú, társasági jogi szakértói csoport összehívására került sor annak érdekében, hogy ajánlásokat fogalmazzon meg a modern európai társasági jogi szabályozórendszer kialakitásához. Az ún. Winter Csoport tagjai számos vállalatirányítási területet is megvizsgáltak, így elsősorban az igazgatók szerepét elemezték, figyelemmel voltak a végrehajtó tevékenységre és a felügyeleti tevékenységet ellátó igazgatói feladatokra, a menedzsment díjaźsának, valamint ennek átláthatóságának szabályozási lehetốségeire, valamint vizsgálták a könyvvizsgálati felelőssség kérdését.

A csoport 2002 novemberében mutatta be jelentését (a továbbiakban: Winter-jelentés) ${ }^{3}$, amely az európai társasági jog modernizációjára, valamint az európai vállalatirányítási szabályokra fókuszált ${ }^{4}$. A szakértót bizottság továbbá javasolta, hogy az Európai Bizottság dolgozzon ki egy társasági jogi cselekvési programot, amit a Bizottság, jelentós mértékben támaszkodva a Winter-csoport jelentésére, 2003 májusában elố is terjesztett. Az akcióterv célja az európai társasági jogi és vállalatirányítási keretrendszer megreformálása volt. 
A cselekvési program három idóintervallumban fogalmaz meg feladatokat és célokat, elkerülendó a kapkodást, a szabályozási feladatok hektikus, és ebbő́l eredőe nem kellóen kimunkált végrehajtását. A program ennek megfelelően rövid (2003-2005), közép- (2006-2008) és hosszú (2009-) távra bontja le azokat a feladatokat és célokat, amelyek a modern és hatékony európai vállalatirányítási környezet kialakításához nélkülözhetetlenek.

Az akcióterv segítségével az EU konkrétan két fố célt szeretne elérn:

megerôsíteni a részvényesek, munkavállalók és hitelezôk védelmét, és

elôsegíteni az üzleti élet versenyképességét, különös gondot fordítva egyes nemzetközi (határon átnyúló) kérdésekre.

A jogszabály-alkotási, illetve egyéb közösségi szintú akciót igénylő javaslatok a következô hat témakö köré szerveződnek: vállalatirányítás, tốkefenntartás és átalakítás, vállalatcsoportok és piramisok, vállalati átszervezés és mobilitás, európai magánvállalat, szövetkezetek és egyéb vállalati formák.

Az Európai Bizottság az Európai Vállalatirányítási Kódex létrehozásának ötletét elvetette, mivel megítélése szerint az túl sok hozzáadott értéket nem képviselne, csak egy újabb réteggel bővítené a szabályozás selne, csa gu úk renk, stan, beckek közé Az akcióterv ugyanakzor lyok, stand turze ki, hogy taǵl Az áciobter ugyanakkor celul túzte ki, hogy tagállanín fokozatos közelitése érdekében létre kell hozni egy rendszeresen ülésező fórumot (European Corporat Governance Forum), amelynek keretei között talá koznak a tagállamok, az európai szabályozók, a kibocsátók, a befektető́k és az akadémiai szektor kép viselői is. A fórum alakuló ülésére 2005 januárjában került sors. A vállalatirányítási szabályokat illetóen megfogalmazódott továbbá egy olyan irányelv kidolgozásának szükségessége, amely a vállalatok éves vállalatirányítási jelentésének fóbb alapelveit határozná meg. Középtávon a Bizottság olyan irányelvterveze elő́rerjesztésćben gondolkodik, amely az intézmény befektetóket kényszerítené arra hogy befektési po-

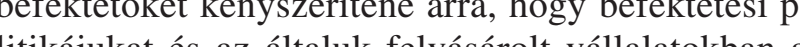
kalmazat é szavaźsi jogokat és eljársokt hozzk kalmazandó szavazasi jogokat és eljárásokat hozz nyilvanossagra, illetve arra is, hogy a tulajdonosok keresere adjanak szamot arró, egyes esetekben hogyan gyakorolták szavazati jogaikat.

A határon átnyúló szavazás megkönnyítése szintén szerepelt a reformintézkedések között, ezáltal is segít ve a külföldi részvényeseknek a vállalati múködésben való részvételét. Az igazgatótanácsokat, az igazgatoságokat érintó reformok meglehetősen gyorsan megin- dultak. Meg kellett állapítani az igazgatóság tagjainak kollektív felelősségét, mivel a pénzügyi kimutatások iránti bizalom ahhoz kapcsolódik, hogy ki visel felelósséget összeállításukért és nyilvánosságra hozatalukért. Bevezették továbbá az ún. vállalatirányítási nyilatkozatot, amely új kötelezettség értelmében minden jegyzett társaságnak - éves jelentésének egy meghatározott részében - információt kell közzétennie saját (vállalatirányítási) gyakorlatáról. A Bizottság ezek mellett még több jelentôs ajánlást fogadott el, követve azt a szemléletet amely a vállalatirányítás terïletén a kötelező erejú szzb́llyoźsi eszközök helyett az ajónlásoktezó ereju

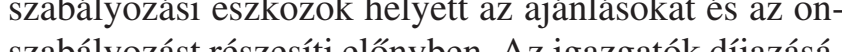
sza (illetve a reszesíti lóñben. Az igazgatók dijazására (illeve alapvetóen on kozóan még 2004-ben fogadak el az ajănást, amelyet 2005-ben kovetett a jegyzett társaságok nem ügyvezetố igazgatói, illetve felügyelóbizottsági tagjai szerepéról és az igazgatóság (felügyelóbizottság) által létrehozott bizottságokról szóló ajánlás? ${ }^{7}$ Ez utóbbi ajánlás annak szellemében készuilt, amely szerint annak biztosítására, hogy a vezetési funkció hatékony és kellóen független felügyeleti funkció alatt álljon, az igazgatóságnak (felügyelóbizottságnak) elegendô számú elkötelezett, nem ügyvezetố taggal vagy felügyelő bizottsági taggal kell rendelkeznie, akik nem játszanak szerepet a vállalat vagy anno csoportja vezetéćcen, ́́s akik fuigget-

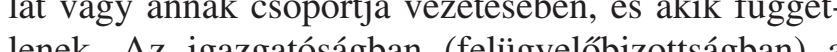
lenck. Az igazgatoságban (felügyelobbizottságban) a független tagok számarányá Kolada (lehetósége) marad.

Konkrét intézkedés volt a cselekvési terv listáján a második társasági jogi irányelv modernizálása és egyszerúsítese a részvenytársaságok alapitása, illetve a tóke megtartása és átalakítása vonatkozásában. Ennek megfelelóen a cselekvési terv a SLIM (az európai jogszabályok egyszerúsítésére létrejott munkacsoport), illetve a Winter Csoport ajánlásai alapján rövid távon megvalósítandó célkitúzésként fogalmazta meg a nehézkes szabályozás módosítását.

A vállalati csoportokra és piramisokra vonatkozóan is jogszabály készült a csoportok pénzügyi és nem pénzügyi információinak közzététele tárgyában.

Az Európai Bizottság 2004 végén fogadta el a vállalati és pénzügyi visszaélésekkel szembeni stratégiáját tartalmazó közleményét, amely a vállalatirányítási szabályozási környezet számára is irányadó. A stratégia a pénzügyi szolgáltatások, a társasági jog, a számvitel, az adózás és a felügyelet területeit is érintve a pénzügyi és üzleti visszaélések visszaszorítása érdekében számos prioritást és végrehajtandó feladatot határozott meg. A dokumentum külön hangsúlyozta a Pénzügyi Szolgáltatási Cselekvési Terv $^{8}$ hatékony végrehajtásának fontosságát a pénzügyi botrányok elkerülése érdekében.
A Cselekvési Terv egyébként teljes körúen megvalósult és a belsố piaci építkezés egyik legnagyobb sikerének tekinthető, még akkor is, ha a pénzügyi válság hatására szinte azonnal szükség volt számos új rendelkezés elókészítésére, bevezetésére. A stratégia kulcsszavai következók voltak: nagyobb transzparencia, fokozot nyomon követhetősség és jobban koordinált jogérvényesítés. A stratégia képezte, illetve képezi a nagy, átfogo vállalatirányítási reform első hullámának gerincét.

Mint már utaltunk rá, a Parmalat-eset (az európa „Enron-ügy”) világossá tette, hogy egyes cégek számviteli és üzletviteli gyakorlata bonyolult és átláthatatlan, és tevékenységük egyre követhetetlenebb a befektetốk és részvényesek számára is. A cél az, hogy olyan védelmi rendszer honosodjon meg Európában, amely az alábbi négy „bástyán” nyugszik

a vállalatok belsô ellenőrzési rendszere, amely fô-

képp az igazgatósági tagok felelősségén alapul.

független auditálás,

felügyelet és ellenôrzés s

végül a törvények betartatása.

Ez az egységes koncepció garantálhatja az európai vállalatirányítási keretrendszer stabilitását és megbízhatóságát (1. ábra).

Az európ

vállalatirányítási keretrendsze

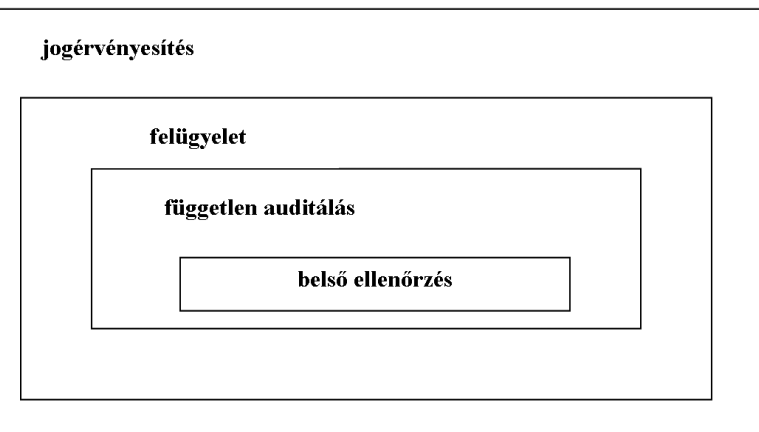

A Parmalat leányvállalatok sokaságával, több offshore céggel rendelkezett a rugalmas jogi, pénzügyi és adôzási kơrnyezet maximális kihasználása erdekében. A védelmi bástyák közül azonban már az első sem

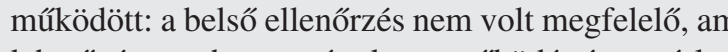
lehetővé tette, hogy a tényleges múködés és a mérlegben szerepló információk es eredmenykimutatások nem fedték egymást. Az auditálás bástyája sem mûködött, noha egyes tanácsadók nyilvánvalóan tudta a tényleges kockázatról, azonban ennek felelôsségét igyekeztek továbbhárítani.
Az adózási területen, kiváltképp a társasági adózás területén, az információcserét és az átláthatóságot kel növelni annak érdekében, hogy az egyre komplexebbé váló vállalati struktúrák dzsungelében fenn lehessen tartani a megfeleló szintú üzletviteli garanciákat. Ennek keretében a kölcsönös segítségnyújtásról szólờ irányelv szorul továbbfejlesztésre: az adózási csalás és adóelkerülés közös európai definícióját pontosabbà kell tenni, lehetôvé kell tenni, hogy a tagállami adóhatóságok között az információáramlás és a tapasztaatcsere az eddiginél intenzívebb és eredményesebb

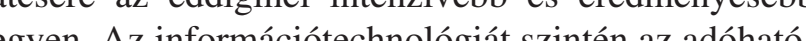
legyen Az infor áco egyit

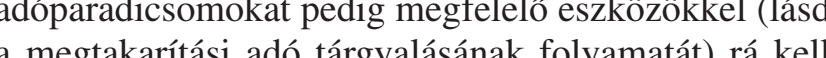
veni e súc venni e státusuk fokozatos feladására, illetve az információcsere és a transzparencia gyakorlására.

Az európai szintú reformok mellett természetesen a tagállamok saját maguk is végzik dolgukat, és megpróbálják vallalatirányítási rendszerüket modernizálni. Ebben Hollandia jár az élen, amely új vállalatirányítási kódexe (nagyon sok tekintetben hasonlít az amerikai Sarbanes-Oxley-törvényre) segítségével rendkívüli eredményeket ért el, és feltornázta magát a világ legtranszparensebb vállalati szektorral rendelkező országai közé. (A GovernanceMetrics 2005 márciusi felmérésében Hollandia, Anglia, Kanada, az USA és Írország mögött a világ 5 . legjobb helyezését kapta a vállalatirányítási rangsorban.) A reformok hatására például azon cégek aránya, ahol nincs szétválasztva az elnöki és a vezérigazgatói poszt két éven belül 47 százalékról 39 százalékra csökkent. Németországban pedig egy olyan törvényt terjesztettek eló 2005 márciusában, amely kötelezővé teszi a vállalatvezetớk fizetésének és egyéb juttatásának nyilvánosságra hozatalát. Ez a tendencia a válság miatt kialakult társadalmi hangulat, illetve a cégvezetók gyakran arcátlan méreteket öltő jutalmai miatt a közelmúltban világszerte felerősödött.

A reformok második, 2007 után induló hullámának jelzálogpiac összeomlásával induló globális gazdasági válság adott nagy lökést. Mindennek a tanulságait jelenleg próbálják leszúrni a tagországok, és próbálják meg lefordítani a jogalkotás, illetve a közösségi szintú ajánlások megalkotásának szintjére. Az új szabályok elsősorban a pénzügyi szolgáltatókat, a pénzügyi piacokat és a hitelminősítő intézeteket fogják érinteni. Érezhető a túlnyomórészt önszabályozásra épülố megközelítés módosulása is: a vészhelyzetben egyre nagyobb a hajlandóság a tagországokban, hogy EU szintű kötelezô szabályokat fogadjanak el, különösen 
azoknak a pénzügyi termékeknek az esetében (pl. fedezeti alapok), ahol eddig globálisan túlzottan szellós volt a szabályozás. Az EU ebben a tekintetben globál szabályalkotó szándékkal is fellép, a közeljövő fogj megmutatni, hogy milyen sikerrel.

A versenyképesség elősegítésének egyik eszköz tehát a vállalatirányítási szabályrendszer modernizációja, amit az előzőekben tárgyaltunk, a másik eszköz amely elősegítheti a kreatív és versenyképes gazdaság kifejlődését és virágzását, az a modern és ütóképes vállalatirányítási (menedzsment) kultúra megléte, illetve kialakítása.

Az innováció, a fejlesztés, amihez viszont sokkal több idő, megfelelő vállalkozás és innovációbarát környezet, és nem utolsósorban kreatív emberek és megfelelő vezetók kellenek. Az általános vállalkozói szellem elengedhetetlen feltétele a fejlódésnek.

\section{Különbségek a globális vezetôi értékrendben}

Egy vezetố nemzetközi humáneróforrás-cég 2005 vé-
gén kétszáz európai cégvezetốt kérdezett meg vezetői gyakorlatáról és értékelt ki. A felmérésben szereplók alapvetốen nagy multinacionális cégek elsó́ embere voltak, akikről joggal feltételezhetnénk, hogy alapvetôen egy egységes globális vezetối értékrend szerint gonen egy egy és cselekszenek A felmérés azon szerint go pő́

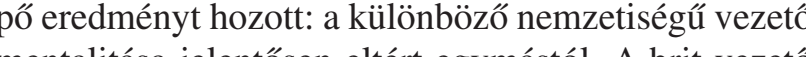
mentalitása jelentósen eltért egymástól. A brit vezetók meritokratáknak, a németek demokratáknak, a franciá autokratáknak bizonyultak. A brit vezetốt nem zavarja, ha döntéseit megkérdőjelezik, a német a szerénység fontosságát hangsúlyozza, a francia pedig élvezi a hatamat, amit az nyújt neki, hogy döntést hozhat, akár munkatársai megkérdezése nélkül is. A francia menedzsere kétharmada, a németek fele és a britek mindössze harmada tartja az egyik legfontosabb dolognak az egyszemélyes, korlátok nélküli döntéshozás lehetôségét. A brit vezetók kétharmada, a németek fele, de alig több min a franciák tizede tartja a három legfontosabb vezetố a franciák tizének a cégen belïli tehetségek kinevelését. A hatalom bitoklása a francia válaszadók körćben

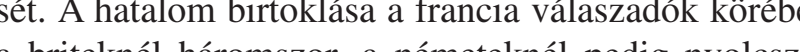
a briteknél háromszor, a néneteknél pedig nyolcszor

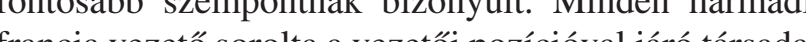
francia vezetó sorolta a vezetói pozícióval járó társadalmi elismerést a három legfontosabb szempont egyike közé, míg mindössze minden hatodik német és minde ötvenedik brit gondolta ezt így. A németek legnagyob félelme a kudarc volt, míg a britek a kudarcot sokka inkább a normál emberi tanulási folyamat részének tekintik. A francia vezetók legnagyobb félelme pedig - az elózốek alapján nem meglepó módon - a cégen beliu „egók” konfliktusai miatt kialakuló feszültségek voltak. Az európai menedzsmentkultúrára igencsak rányomja a bélyegét a nemzeti hovatartozás kérdése. Az Aspen és Economic Intelligence Unit felmérése, amelyet 450 nagy európai cég körében végeztek, lesújtó eredményt hozott. A vizsgált 75 olasz cégból csak egynek volt külföldi (francia) vezetôje. A 75 francia cégból kettoónek, a 75-75 skandináv és spanyol cégből pedig háromnak, illetve négynek volt külföldi főnöke. Németországban és Nagy-Britanniában sokkal jobb volt az arány (12, illetve 26), vagyis ezek az országok sokkal inkább képességeket, mint a nemzeti hovatartozást halyeźćk képességeket, mint a nemzeti hovatartozást helyezték elôtérbe. A vizsgált 75 francia cég vezetőjéból 33 érkezett az ország két gazdasági elitegyeteméról, az École Colytechnique-ró, illetve az École des Hautes Études Commerciales-ról. Az európai felsó vezetók kiválasztásában mintha sem a közös piac több évtizeddel ezelótti létrejötte, sem a globalizáció nem játszana semmilyen szerepet sem, annál inkább fontos a nemzetiség és a diplomát adó intézmény presztízse. Ez is európai jelenség. Hiszen amellett, hogy a vállalkozási és vállalatvezetési ismeretek oktatása egyelóre igen specializált, szinte kizárólag közgazdasági egyetemeken és business schoolokon folyik, a „papírnak” igen nagy tisztelete és szerepe van az elórejutásban Sokkal nagyobb, mint szerepe van az elôrejutásban. Sokkal nagyobb, mint Amerikaban. Üssük csak be Sergey Brin nevét az általa Google-ba, és azt kapjuk, hogy az orosz bevándorló feltaláló felfüggesztette doktori tanulmányait a Stanford Egyetemen. A Harvardot idó elốt otthagyó Gatesról már ne is beszéljünk. „Legyél dühös, ne közgazdász!" - mondja Anita Roddick, a Body Shop multimilliomos alapítója. Az európai vállalkozóknak és vállalatvezetốknek sokat kell tanulniuk, nem utolsósorban hozzá kell szokniuk a turbóglobalizáció korának kíméletlen piaci jelenségeihez, mint például a hagyományosan bankkölcsönökból fejlesztố német vállalatoknak az ellenséges felvásárlásokhoz, a tôzsdei jelenlét okozta bonyolult jelentéstételi és transzparenciaszabályokhoz. Vagy ahhoz, hogy a hagyományos korporatív struktúrák, amelyek alapia a nagy cécek és beszállitóik egy-

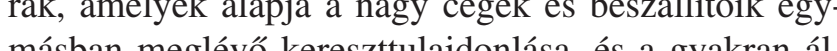
lami bankokat, vagy egyenesen az alla gyakran álla bi ba a helyi önkormányzatokkal való jó viszony fenntartása hán irányítasi rendszer már átesett, és nagyban hozzájárult a finn gazdasági csoda kialakulásához. Amíg ez nem történik meg, addig elmosódnak a vállalkozás és az állami beavatkozás határa

Egy 2009-es felmérés szerint túlságosan öreg emberekbốl álnak és túlságosan ritkán üléseznek az európai vállalati igazgatótanácsok és felügyelőbizottságok, különösen érvényes ez a német cégekre. A Heidrick
\& Struggles személyzeti tanácsadó cég Európa 13 országában összesen 371 nagyvállalat igazgatótanácsé és felügyelóbizottságát vonta be felmérésébe. (Az és az fb különválasztása jellemzô a német, az oszrák, a svájci, a dán, a holland és a finn társasági jogra. Nagy-Britanniában, Olasz- és Spanyolországba ezzel szemben általában egyazon testület tölti be az operatív igazgatási és a tulajdonosok érdekeit nézó felügyeleti feladatokat, míg Franciaország, Svédország, Belgium és Portugália vegyes rendszert alkalmaz. A pénzügyi válság, a német közéletet az utóbbi években

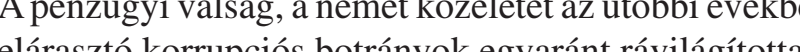
méńl múködik nem jôn lában Európában. A tanulmány szerint a legjobban a br és a holland igazgatótanácsok és felügyelóbizottságok töltik be küldetésüket. Viszonylag jól múködnek az it-k és az fb-k a svájci, svéd, finn és francia nagyvállalatoknál is. Az európai vállalatok igazgatóságában és felügyelóbizottságában helyet foglaló tagok átlagéletkora 59 év (Németországban 60), és évente átlagosa 9,6 alkalommal üléseznek. Egy átlagos it- vagy fb-tag 5,5 évet tölt el pozíciójában. Az it-k és az fb-k átlagos létszáma 11,8 fó, de ebból csak 1,2 tag nő. A külföld vezetók aránya Hollandiában a legmagasabb, 54 százalékos - Spanyolországban ezzel szemben csupán 10 Némos - Spanyolországban ezzel szz

Ha Európának sok tanulnivalója van vállalkozásból, akkor Japánnak még több. Az államilag aprólékosan megtervezett gazdaságpolitika és az annak alapján létrehozott megavállalatok, a keiretsuk egykor a világ legfélelmetesebb fegyvereinek számítottak. Ma már látható, hogy az idejük lejárt, csakúgy, mint a mások ötleteinek adaptálására és tökéletesítésére alapuló fejlesztéspolitika. Az imitációt ma már az innovációnak kell felváltania. Japán természetesen hatalmas kutatásfejlesztési eredményeket ért el, és a robotikában ma is verhetetlen, de úgy tủnik, gazdasági modellje zsákutcába jutott, és helyzete a nála tízszer nagyobb Kína felemelkedésével tovább nehezedik. Japán legnagyobb ellenfele azonban nem Kína, hanem az hogy nincsenek önálló gondolkodni képes, kockázatválló nís ksenek ôn medig múköd (igaz, ebben az esetben szinte tokéletesen), amíg nin szúkség irányvaltásta, a mogszokott nintáktó való térésre. Ha viszont eljôn ez az idó, a rendszer lebénu mert nincs, aki mozgassa. A turbóglobalizáció idejé azonban az egyenes szakaszok egyre rövidebbek, a kanyarok pedig egyre élesebbek lesznek. A siker titka az oktatás, a kutatásfejlesztés és az innováció szoros és gyümölcsözô kapcsolatának megteremtése. A magas színvonalon képzett egyetemisták úttörố kutatási eredményein alapuló sikeres hi-tech cégek, amelyek mun- kahelyeket teremtenek, külföldi piacokat szereznek, nemzetközi szabadalmakat birtokolnak, esetleg még Az ozi szabvanyokat is teremtene

$\mathrm{Az}$ amerikai MIT (Massachusetts Institute of Technology) - amely a világ legfontosabb technikai tudásgyarának számít - mintájára az Európai Unió is elindított egy ehhez hasonló, de az MIT-hez képest sokkal lazább intézményi keretek között múködtetendő tudásközpontot: az EITI-t (European Institute of Technology and Innovation $)^{10}$. Az intézmény krédója énen a mágikus háromszög (közkeletún nevén a tudás vagyis az oktatás, a asznositásának - az innovációnak - az egy helyre telo prése. Ezek a tudássejtek - amelyek oktatókból, kutókból és hi-tech vállalkozókból állnának - lennének Eurơpa , "tudás-kutatás-innováció háromszögei”. Az ötet - amelyet nem övezett egyértelmú lelkesedés a kutatói és egyetemi szferra részérốl az induláskor - valódi múködésbe lendülésére még néhány évet várni kell. Nyilvánvaló, hogy egy ilyen projekt, bármilyen fontos, szimbolikus szerepe is van, csak csepp a tengerben: az európai mentalitást kell megváltoztatni. Gondolkodásunk természetes részévé kell válnia az oktatás, a kutatásfejlesztés és az innováció összzekapcsolásának.

Az üzleti ismeretek oktatása területén - jóllehet van Aź tuzleti isméć in

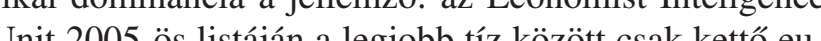
Unit 2005 ös list ajan a legjobb tíz között csak kettô euópai található, csakúgy, mint a Financial Times 2006-os angsoran. A mai nyugat-európai fiatalok generaciójának kell magyarázni, hogy a képzés célja nem egy diploma, ami biztonságos, nyugdíjas állásra jogosít az államigazgatásban. Jobb, ha elhiszik, és nem a „globalizáció” tanítja meg ôket - a kínai és indiai tudásmanufaktúrákban milliónyi mérnök lép a piacra -, mert az könnyen kiábrándultsághoz vezet. Ez pedig rossz tanácsadó. Ha úgy fognák fel a tanulást, mint a legfontosabb eszközt az „élet” versenyében való sikeres részvételhez, számos fusztrációtól kímélnék meg magukat A politika feldata ennek a szemléletmódnak az elterjesztése. Nemcsak a szenćletnóddal, de az intézményrendszerel is

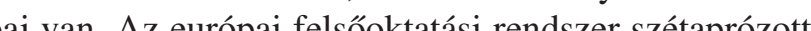
lig vannak globálisan kiemelkedó egyetementón jóle-

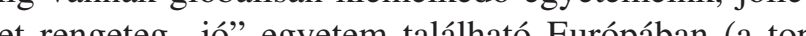
20 egyetem közuil csetén tát európai varópában (a top en eurónai van). A képességek essajátításával nincsen baj Európában, hiszen az oktatás es a felsơoktatás szinvonala rendkívül magas mind a matematika, mind a természettudomanyos ismeretek tekintetében. A probléma a következő lépésnél kezdódik. Az európai egyetemi reformok, amelyek az intézmények finanszírozását piacibb alapokra helyezik (saját bevételek 
generálásával, cégek, alapítványok által) több európai országban folynak. Finnország például 2007 elejétől újította meg egyetemi finanszírozási rendszerét, lehetôvé téve az állami egyetemeknek, hogy üzletorientáltabb költségvetésük legyen és intenzívebb kapcsolatuk alakuljon ki a magánszférával.

Az európai versenyképesség igazi letéteményesei a versenyképesen múködő vállalatok, a tudástôke, illetve a kreatív vállalkozók és vállalatvezetók, sokkal inkább, mint a versenyképesség növelésére irányuló politikai programok és deklarációk. A politika felelőssége, hogy a szükséges szabályozó- és ösztönzőrendszert megalkossa, és garantálja annak stabilitását.

A gazdasági világválság ebben a tekintetben Európa számára akár még áldásos is lehet, hiszen történelmi esélyt adhat az európai szabályalkotóknak, hogy az új globális gazdaság- és vállalatirányítási szabályok (elsôsorban a pénzügyi szektorra vonatkozóan) létrehozásában kulcsszerepet játsszon.

\section{Lábjegyzet}

${ }^{1}$ Pl. a Bizottság 2004. december 14-i ajánlása a megfelelő rendszer előmozdításáról a jegyzett társaságok igazgatóinak díjazása érdekében (2004/913/EK), a Bizottság 2005. február 15-i ajánlása a jegyzett társaságok nem ügyvezetó igazgatói, illetve felügyelóbizottsági tagjai szerepéról és az igazgatóság (felügyelóbizottság) által létrehozott bizottságokról (2005/162).

2 A hételemes megoldási javaslat részelemei a következók: a piaczavarásról szóló (market abuse) irányelv elfogadása a tisztességes piaci magatartás elómozdítása érdekében, a vállalatirányítás reformja, a számviteli szabványok, előírások modernizálása, az auditszakmára vonatkozó előírások javítása, a pénzügyi elemzókre és tanácsadókra vonatkozó előírások javítása, a pénzügyi intézményekre vonatkozó prudenciális elő́rások szigorítása, a tôzsdei kereskedésben részt vevő cégekre vonatkozó nyilvánosságra hozatali és transzparencia-elóírások erősítése.

${ }^{3}$ Final Report of the High Level Group of Company Law Experts chaired by Jaap Winter.
${ }^{4}$ A Versenyképességi Tanács 2002. szeptemberi ülésén felhívta a Bizottságot, hogy a tagállamokkal történó konzultációkat követóen dolgozzon ki akciótervet a társasági jog modernizációja érdekében, a vállalatirányítási kérdésekre is kiterjedően, amely igényt az Európai Tanács is megerósített 2003. márciusi ülésén.

5 A Bizottság 2004. október 15-i 2004/706/EK határozata.

${ }^{6}$ A Bizottság 2004. december 14-i ajánlása megfelelő rendszer előmozdításáról a jegyzett társaságok igazgatóinak díjazása érdekében (2004/913/EK).

7 A Bizottság 2005. február 15-i ajánlása a jegyzett társaságok nem ügyvezetô igazgatói, illetve felügyelóbizottsági tagjai szerepéról és az igazgatóság (felügyelóbizottság) által létrehozott bizottságokról (2005/162).

${ }^{8}$ COM (1999) 232, továbbá a 2005. május 3-i Zöld Könyv a pénzügyi szolgáltatások politikájáról.

${ }^{9}$ Lásd részletesebben: Marján Attila: Az Európai Unió gazdasága, HVG, 2006.

10 Lásd részletesen az intézmény statutumát: Az Európai Parlament és a Tanács 294/2008/EK rendelete (2008. március 11.) az Európai Innovációs Technológiai Intézet létrehozásáról.

\section{Felhasznált irodalom}

Centre for European Reform (2006): EU 2010 - A programme for reform - Manifesto, Brussels

Lewis, William W. (2004): The Power of Productivity: Wealth, Poverty, and the Threat to Global Stability, The University of Chicago Press, McKinsey \& Co

Marján A. (2007): Európa sorsa - Az öreg hölgy és a bika. HVG Könyvek, Budapest

Marján A. (2006): Az Európai Unió gazdasága - minden, amit az EU gazdasági szakpolitikáiról tudni kell. HVG Könyvek, Budapest

Pisani-Ferry, J. - Sapir A. (2006): Last exit to Lisbon, Bruegel Policy Brief, 14 March

Szalai Z. (1998): Értékpapír-befektetés az Európai Unióban, MNB Múhelytanulmányok, 14. március

Cikk beérkezett: 2009. 3. hó

Lektori vélemény alapján véglegesítve: 2009. 8. hó 